\title{
HVMANITAS
}

\section{Algunos hitos de tradición clasica en el "Gavinete de antigüedades y humanidades" (Madrid, 1802) de Juan de Salas Calderón}

Autor(es): Jerez, Luis Merino Publicado por: $\begin{aligned} & \text { Faculdade de Letras da Universidade de Coimbra, Instituto de Estudos } \\ & \text { Clássicos }\end{aligned}$

URL persistente:

URI:http://hdl.handle.net/10316.2/27954

DOI: $\quad$ DOI:http://dx.doi.org/10.14195/2183-1718_60_18

Accessed : $\quad$ 26-Apr-2023 15:07:00

A navegação consulta e descarregamento dos títulos inseridos nas Bibliotecas Digitais UC Digitalis, UC Pombalina e UC Impactum, pressupõem a aceitação plena e sem reservas dos Termos e Condições de Uso destas Bibliotecas Digitais, disponíveis em https://digitalis.uc.pt/pt-pt/termos.

Conforme exposto nos referidos Termos e Condições de Uso, o descarregamento de títulos de acesso restrito requer uma licença válida de autorização devendo o utilizador aceder ao(s) documento(s) a partir de um endereço de IP da instituição detentora da supramencionada licença.

Ao utilizador é apenas permitido o descarregamento para uso pessoal, pelo que o emprego do(s) título(s) descarregado(s) para outro fim, designadamente comercial, carece de autorização do respetivo autor ou editor da obra.

Na medida em que todas as obras da UC Digitalis se encontram protegidas pelo Código do Direito de Autor e Direitos Conexos e demais legislação aplicável, toda a cópia, parcial ou total, deste documento, nos casos em que é legalmente admitida, deverá conter ou fazer-se acompanhar por este aviso. 
humanitas

\section{Vol. LX}

IMPRENSA DA UNIVERSIDADE DE COIMBRA

COIMBRA UNIVERSITY PRESS 


\title{
ALGUNOS HITOS DE TRADICIÓN CLÁSICA EN EL GAVINETE DE ANTIGÜEDADES Y HUMANIDADES (MADRID, 1802) DE JUAN DE SALAS CALDERÓN*
}

\author{
Luis Merino Jerez \\ Universidad de Extremadura \\ lmerino@unex.es
}

\section{Resumen}

El Gavinete de antigüedades de Juan de Salas Calderón (1802) contiene numerosas fuentes clásicas (Virgilio y Horacio) y modernas (los Adagia de Erasmo, los Hieroglyphica de Piero Valeriano y los Emblemata de Alciato). El Gavinete se inspira en los Saturnalia de Macrobio y pretende, como Horacio, enseñar deleitando. emblemas.

Palabras clave: Tradición clásica, Salas Calderón, Horacio, adagios y

\section{Abstract}

The Gavinete de antiguiedades of Juan de Salas Calderón (1802) contains many classic (Horace and Virgil) and modern sources (Adagia, Hieroglyphica and Emblemata). The Gavinete it is inspired by Satumalia of Macrobius and it tries to docere delectando, so as it recommends Horace in its Ars poetica.

Keywords: Classic tradition, Salas Calderón, Horace, adagia and emblems.

* Agradezco al Prof. S. López Moreda las atinadas sugerencias que me ha hecho para la elaboración de este trabajo. También deseo dejar constancia de mi gratitud y afecto al Prof. Sebastião Tavares de Pinho. 


\section{Sobre el Gavinete y su autor}

La vida de Juan de Salas es poco conocida y las pocas certezas que tenemos proceden del prólogo y de algunos pasajes de su Gavinete de antigüedades, pues el resto de las noticias son acaso invención del insigne bibliófilo Antonio Rodríguez Moñino ${ }^{1}$. Del relato biográfico elaborado supuestamente por Moñino se hace amplio eco M. Mañas, a quien podemos acudir para reconstruir lo fundamental de la biografía de este curioso personaje ${ }^{2}$. Bástenos saber, no obstante, que Juan de Salas Calderón nació en Extremadura, más concretamente en Siruela ${ }^{3}$, y que ejercía en Madrid como abogado, aunque, según parece, viajaba con frecuencia a Badajoz, donde pasaba largas estancias. Además era un hombre acaudalado, amigo del poeta Manuel de la Rocha y protegido, al parecer, del mismísimo Príncipe de la paz, Manuel Godoy ${ }^{4}$.

El Gavinete de antigüedades es la única obra conocida de Juan de Salas Calderón. En la portada del tomo primero se anuncia el propósito del poeta: comentar y explicar diferentes aspectos de la antigüedad grecolatina de acuerdo con el modelo formal que toma prestado de los Saturnalia de Macrobio $^{5}$. Pero antes de comentar las disquisiciones sobre diferentes aspectos del mundo clásico que se encuentran en el Gavinete, conviene llamar la atención sobre el hecho de que esta obra contiene algunos epigramas escritos en latín, así como la traducción de algunos textos de Horacio y Séneca. Fue posiblemente la decisión de componer los epigramas latinos lo que en buena medida llevó al autor a profundizar en

${ }^{1} \mathrm{El}$ Gavinete de antigüedades y humanidades consta de tres tomos, aunque en este trabajo nos limitamos a comentar algunos aspectos señeros del primero, dejando para mejor ocasión la consideración de los dos últimos. Los tres ejemplares pueden consultarse en la Biblioteca de Humanidades de la Universidad de Navarra. La narración atribuida a A. Rodríguez Moñino está fechada en 1928 y se encuentra recogida en R. Rodríguez Moñino 2000: 33-34.

${ }^{2}$ M. Mañas 2004: 499-508.

${ }^{3}$ Salas 1802: 241.

${ }^{4} \mathrm{M}$. Mañas 2004: 501-502; también se hace eco de este perfil biográfico C. Chaparro 2003: 125-143.

5 "Gavinete [...] en que imitando la idea de Macrobio en sus Convites saturnales se tocan y explican varios puntos de antigüedad y humanidad, y se tratan otras especies divertidas y curiosas" (Salas 1802: 1). 
el estudio y la traducción de los textos clásicos. El resultado de su trabajo de documentación se vierte en las conversaciones que mantienen a lo largo de tres jornadas sucesivas otros tantos personajes: don Anselmo, don Feliciano y don Modesto. Efectivamente, Salas quiso contribuir a la visita que realizaron los reyes Carlos IV y María Luisa de Parma a la ciudad de Badajoz, acompañados de Manuel Godoy, más conocido como "el Príncipe de la paz". Pretendía el poeta que estos epigramas, acompañados de algunas ilustraciones simbólicas, engalanaran las calles de la ciudad pacense al paso de la comitiva regia. Sin embargo, no pudo concluir su obra a tiempo. De hecho, de estos epigramas latinos se conservan dos versiones: una primera, manuscrita y casi torpe ${ }^{6}$, y otra, mucho más pulida, impresa en el tomo primero del Gavinete de antigüedades y, por tanto, posterior a la visita real. Del contenido, formas, fuentes e intención de estos epigramas latinos, así como de las variantes entre la primera y la segunda versión ha dado cumplida cuenta M. Mañas en el Florilegio de estudios de emblemática. Concluye Mañas que "literariamente, los epigramas no son de gran calidad" y que "el autor acude, como es habitual en los poetas neolatinos, a lo que se ha llamado latín de laboratorio", que, como es sabido, consiste en trenzar junturas léxicas y sintácticas de los autores clásicos para obtener un nuevo producto literario, a partir del diferente sentido que alcanzan los retazos clásicos en el nuevo contexto en el que se insertan. El análisis pone

${ }^{6}$ Esta primera versión se conserva en un manuscrito del fondo Clot-Manzanares de la Biblioteca de Extremadura y puede leerse en la edición facsímil que promovió el Ayuntamiento de Badajoz: Godoy. Principe de la Paz. Edición facsimilar de tres manuscritos relacionados con la figura de Manuel Godoy y la ciudad de Badajoz, Badajoz, 2001. J. García (2006: 177-188) pone de manifiesto las numerosas incorrecciones métricas de esta primera entrega, reconocidas ya, todo hay que decirlo, por el propio Salas en la segunda versión, esto es, la impresa en el tomo I del Gavinete: "Algunos (defectos) tiene (...) en la versificación, pero los hace disimulables la prisa y precipitación con que, porque llegasen a tiempo, es de creerse los dispusiese su autor: las sinalefas amontonadas y que algunas hieren en diptongo. (...) Pero ya he dicho que estos y otros defectos puede disimularlos la consideración de que el autor no podría ponerlos la última lima (...). En esta clase de producciones salen pocas perfectas, porque son muchas y muy estrechas las leyes de la versificación latina y muy dificil el hacer versos en idioma que no sea el vernáculo, por bien que se posea" (Salas 1802: 235-237). 
de manifiesto la influencia de los emblemas de Alciato, cosa relativamente lógica ${ }^{7}$ si tenemos en cuenta que estos epigramas irían, en principio, acompañados de imágenes que a la manera de emblemas jalonaban el recorrido regio, de acuerdo con los usos propios de esta manifestación de arte efimero ${ }^{8}$.

Más recientemente, C. Chaparro ha advertido el interés de Salas Calderón por Horacio, en un artículo que analiza la traducción que el ilustrado extremeño hiciera de la oda 1.12 de Horacio, en parangón con las traducciones renacentistas de Juan de Almeida, Francisco Sánchez de las Brozas "El Brocense", Alonso de Espinosa y Fray Luis de León. Chaparro considera "meritoria" la traducción de Salas Calderón pero añade que no estaría de más "un repaso, enmienda o rectificación" de su trabajo como traductor'. En fin, el tomo primero del Gavinete contiene otras traducciones de Horacio aún por estudiar y un amplio fragmento de la tragedia Thiestes de Séneca ${ }^{10}$. Todas estas traducciones y las correspondientes versiones latinas están recogidas en un Apéndice final al tomo I. En esta relación de poemas líricos el lector de ayer y de hoy puede verse sorprendido por la inclusión del acto $\mathrm{V}$ de la tragedia Thiestes de Séneca y, tal vez por ser consciente de ello, el propio Salas explica las razones de su presencia en el repertorio de traducciones horacianas. En la primera nota a la traducción del Thiestes advierte que:

"El fuego y entusiasmo poético de Lucio Anneo Séneca luce y resplandece en sus tragedias, las cuales son uno de los monumentos preciosos de la

${ }^{7} \mathrm{He}$ escrito "relativamente" porque entre la publicación de los Emblemas de Alciato, a mediados del s. XVI, y la composición de estos epigramas, a finales del siglo XVIII, han pasado más de dos siglos, largos y bien cargados de nuevos emblemas y nuevas empresas, a los que hubiera podido acudir nuestro autor con igual autoridad. Cf., entre otros, Diego de Saavedra Fajardo, Idea de un principe político cristiano representada en cien empresas, Milano, 1642; o Juan de Solórzano Pereira, Emblemata regio-politica in centuriam una redacta, Madrid, 1610.

${ }^{8}$ En cuanto a lo estrictamente literario, el análisis de Mañas destaca la preferencia de Salas por Ovidio, sobre todo por las narraciones mitológicas contenidas en las Metamorfosis. M. Mañas 2004: 508-509.

${ }^{9}$ Cf. Hor., Carm. 1.12. Chaparro 2003: 143.

${ }^{10}$ Efectivamente, a la Oda 1.12 , le siguen estas otras: $2.11 ; 4.7 ; 5.2$; los epodos $5.7 ; 5.9$; y la sátira 1.9 . 
literatura antigua y nos demuestran el estado de perfección y arreglo, propiedad y buen gusto en que en Roma llegaron a estar los teatros y la poesía dramática" (Salas 1802: 118 Apéndice).

Así pues, a la admiración sincera por los versos de Séneca hay que añadir el deseo de contribuir a lo que el autor llama la resurrección del "arreglo y el buen gusto" en el teatro de su época. En este sentido, la traducción de Séneca debería servir, en opinión de Salas, para fortalecer la influencia del teatro clásico en la dramaturgia de comienzos de siglo. Por otra parte, su traducción se reduce al acto quinto, circunstancia que se explica, según dice, por ser éste un texto que tiene unidad de sentido ${ }^{11}$.

\section{Las fuentes clásicas del Gavinete: Horacio y Virgilio}

En este punto, como en otros, Salas Calderón exhibe un clasicismo militante que tiene de nuevo en Horacio a su principal mentor. A cada paso Salas acude a los versos de Horacio y, sobre todo, a los del Ars poetica para teorizar sobre los usos literarios y artísticos de su época. Veamos algunos ejemplos.

Al hilo de una curiosa conversación sobre la conveniencia de que las damas recuperen el uso del zueco, básicamente por la utilidad que presta al proteger del lodo los calzados preciosos que entonces calzaban las señoras petimetras, uno de los conferenciantes invita a disertar sobre el cothurnus y el soccus, que, como es bien sabido, son los calzados al uso en la tragedia y en la comedia, respectivamente. Conforme al propósito del Gavinete, don Modesto, a la sazón en el uso de la palabra, advierte que la disertación ha de ser limitada al origen que tuvieron los dramas y "en lo que a la materia sea concerniente a puntos de antigüedad". Pues bien, una buena parte de la doctrina que leemos aquí sobre el teatro antiguo procede directamente del Ars poetica de Horacio: "Nada dejaron nuestros dramaturgos sin intentar", dice Horacio, y, sin embargo, apostilla Salas, el teatro clásico supo

${ }^{11}$ Salas 1802: 118 (Apéndice) "tuve que ceñirme y limitarme a solo al acto quinto porque no me permitieron la versión de lo demás de la pieza algunas cláusulas y expresiones de que está salpicado el segundo (acto) y por ello tuve que ceñirme al quinto, que es el que admite sección y separación de los demás, sin que se eche mucho de ver que es parte y fragmento de toda la pieza". 
guardar la propiedad de los términos, es decir, en palabras del propio Salas: "no hicieron comedias sobre asuntos y hechos heroicos, ni introduxeron en ellas personajes elevados e ilustres, ni al contrario" (Salas 1802: 131) ${ }^{12}$. La ruptura de esta regla por parte de Lope de Vega supuso la invención de la tragicomedia, un género que no merece el aplauso del autor del Gavinete. Sin embargo, Salas pone de manifiesto su admiración por el talento de Lope de Vega y lo hace, por cierto, en términos parecidos a los que usa en el elogio de Séneca ${ }^{13}$.

A Salas Calderón no le agrada que el teatro de su época respete poco el precepto horaciano que exige unidad ${ }^{14}$ y menos aún que se altere la propiedad necesaria en los respectivos estilos de la tragedia y la comedia, de acuerdo también con lo que dice Horacio en el Ars poetica ${ }^{15}$, pero al final parece rendirse a la evidencia y reconoce que "en todo esto tuvieron no una sola disculpa Lope y los demás que le siguieron". Entre las circunstancias atenuantes cita un testimonio muy autorizado:

"el mismo Horacio no abominó que alguna vez la comedia se hinche y eleve al estilo trágico, y la tragedia alguna vez adopte el vulgar y humilde" (Salas 1802: 135) ${ }^{16}$.

Con todo, el principal argumento que permite exculpar a Lope y a sus secuaces es la necesidad de que el teatro se someta al gusto del público ${ }^{17}$.

12 Cf. Hor., Ars 285: Nit intentatum nostri liquere poetae. Sigo la excelente edición de M. Mañas 2006.

${ }^{13}$ Salas 1802: 131-132. "El entusiasmo y el elevado fuego de su feliz y fecundo ingenio pudo mover a nuestro Lope a romper la valla y, dispensándose a sí mismo, desconcertar todas las antiguas reglas, y rompiendo los límites y diques en que se contenían separadas una y otra composición, confundirlas entre sí y hacer una tercera especie, que puede llamarse tragicomedia".

${ }^{14}$ Hor, Ars 24: Denique sit quod vis simplex dumtaxat et unum.

${ }^{15}$ Hor., Ars 89-92.

${ }^{16}$ Alude evidentemente a Hor, Ars 93.

17 "Además de esto (Horacio) aconseja que el escritor se acomode y observe el uso, el gusto y las costumbres que, variando según su mudable naturaleza y según los años y tiempos, por fuerza a de hacer variar las reglas de la composición dramática. Y poco antes había dado y prescrito una eficacia legislativa al uso en cuyo arbitrio y potestad está el alterar y trocar las cosas" (Salas 1802: 135-136). Salas glosa así el pasaje correspondiente del Ars poetica (70-72): multa renascentur 
En conclusión, las novedades de la tragicomedia en cuanto a unidad, estilo y propiedad se disculpan al amparo de la doctrina horaciana ${ }^{18}$.

Otros pasajes hay en los que el Ars poetica de Horacio presta las doctrinas para la defensa de una estética genuinamente clasicista. Éste es el caso de la anécdota protagonizada por un "cura ignorante" que muestra orgulloso un lienzo en el que está representada "la última cena". Don Feliciano - sin duda, el conferenciante más jocoso -, recuerda las muchas impropiedades del cuadro, como el suelo jaspeado de pizarras de colores, "la mesa redonda, el mantel hasta el suelo, una gran fuente con un ave asada (y no un cordero), y todos sentados en sus banquillos sin respaldo". Cristo, para colmo, "estaba afeitado como un abate", y no con la barba propia de un nazareno de su época. La relación de todas estos errores le lleva a recordar los versos famosos de Horacio:

"pero los pintores y poetas siempre tuvieron igual facultad de fingir según su antojo, como lo notó Horacio en su Arte poética; mas deberían usar de ella con la templanza y modo que él mismo aconseja y no excederse a fingir y expresar en sus poesías y en sus lienzos monstruosidades, impropiedades y anacronismos, que desluzcan el mérito de la obra y descubran la ignorancia del autor" (Salas 1802: 102-103) ${ }^{19}$.

Horacio presta las ideas y las palabras para definir la propiedad de la obra de arte (plástica o literaria), que, para Salas Calderón, constituye un criterio decisivo a la hora de distinguir el buen arte del que no lo es. En este mismo sentido denuncia el anacronismo de otro lienzo en el que un individuo ataviado con el hábito de la orden de Santiago ("vestido a la española antigua") asiste, sin más, al descendimiento de la cruz del cuerpo

quae iam cecidere, cadentque / quae nunc sunt in honore vocabula, si volet usus, / quem penes arbitrium est et ius et norma loquendi.

18 " $y$ en este supuesto son disculpables nuestros escritores, que se acomodaron al gusto del tiempo en que escribían y se separaron de las reglas que no conformaban con él" (Salas 1802: 137).

${ }^{19}$ Alude a un pasaje bien conocido del texto de Horacio (Ars 9-13): 'pictoribus atque poetis / quidlibet audendi semper fuit aequa potestas'. / scimus, et hanc veniam petimusque damusque vicissim; / sed non ut placidis coeant immitia, non ut / serpentes avibus geminentur, tigribus agni. 
de Jesucristo. Por el contrario, propone el Apolo de Belvedere o el grupo escultórico del Laocoonte como modelos artísticos, por la absoluta propiedad de los elementos que lo componen ${ }^{20}$.

Además de Horacio, otros autores antiguos aparecen citados en diferentes pasajes de la obra, como Suetonio y Séneca. Sin embargo, de entre los clásicos Virgilio es el más frecuentado. Tanto es así que significativamente las tres jornadas del tomo primero se cierran con otras tantas referencias a los versos de Virgilio. Al concluir la primera jornada de este debate convivial, leemos:

"Ya es preciso suspender nuestra conversación, porque ya estamos en la precisión de separarnos, pues se hace tarde. Et iam summa procul villarum culmina fumant" (Salas 1802: 73).

Se trata, como es sabido, del penúltimo verso de la égloga primera de Virgilio, en donde, mediante una sinécdoque, en la que reparan ya algunos gramáticos tardíos, se alude al atardecer ${ }^{21}$. El mismo personaje saca a colación otros versos de Virgilio para concluir los libros segundo y tercero:

"En esto cerró el sol y principiaban las horas de la noche y don Feliciano dixo, señores, ya basta por hoy, $[\ldots]$ la hora nos precisa ya a separarnos y descansar; ya basta y quédese algo para mañana, y pongamos a la conversación de este día el fin con que el mismo Virgilio (ya que éste nos ha hecho hoy la principal costa) concluyó la égloga 3: claudite iam rivos, pueri: sat prata biberunt" (Salas 1802: 162-163) ${ }^{22}$.

Se trata del final de la tercera égloga; una conocida alegoría en la que se invita a concluir el canto, por considerar que ya se ha escuchado

20 "Una de las cosas que hacen maravillosas, célebres y portentos del arte al Apolo de Velveder (sic), al grupo de Laocoonte y a otras preciosidades que se conservan y admiran en los jardines, galerías y museos de Italia es el estar exentas de la menor impropiedad" (Salas 1802: 103).

${ }^{21}$ Verg., ecl. 83. Cf. Sacerd., gramm. 6.1.468: Synecdoche est oratio plus minusve dicens, quam necessaria postulat significatio. Haec fit modis quattuor: (...) per id quod sequitur illud quod debuisset dici, ut est 'et iam summa procul villarum culmina fumant', cum debuisset praeponere vesperam factam.

${ }^{22}$ Verg., ed. 3.111. 
bastante, según explica, por ejemplo, Servio ${ }^{23}$. El mismo tono alegórico encontramos en el verso 61 de la Égloga 8 de Virgilio:

"Podemos ya decir con Virgilio desine Maenalios, iam desine, tibia, versus, pues ya la tarde y el año van dando las últimas boqueadas, y nos acuerdan que ya es hora de hacer punto en la conferencia de este día" (Salas 1802: $252)^{24}$.

Añádase a esto que una buena parte de los comentarios hechos en el libro segundo, tal como se reconoce en la conclusión del mismo, gira en torno a los ritos paganos y se dilucida, en gran medida, sobre textos de Virgilio. No viene al caso recoger aquí los numerosos pasajes concretos a los que acuden los interlocutores para desentrañar los arcanos de los sacrificios antiguos y otras curiosidades relativas a esta cuestión. En cualquier caso, en este punto asistimos a una sorprendente disquisición filológica que no tiene parangón en otros pasajes de este primer tomo. Se trata del verso 77 de la Égloga 3 de Virgilio: cum faciam vitula pro frugibus, ipse venito.

"El tal versillo ha atormentado mucho a los ingenios", se dice en el Gavinete, donde se resuelve el presunto enigma aceptando la existencia del verbo vitulari, que significaba lo mismo, dice Salas, que voce laetari. Conforme a la explicación de Macrobio y un ejemplo bien traído de Festo, Salas Calderón cree descubrir el verdadero sentido del verso que, "en mi concepto", dice, "no es otro que convidar Dámetas a Yola a que venga al sacrificio de vitulación o de alegría que pensaba hacer por la conservación y fertilidad de las mieses" (Salas 1802: 76-77) ${ }^{25}$.

Queda claro, pues, que Salas Calderón es un buen conocedor de los textos clásicos. Tiene gran familiariad con Virgilio y con otros autores clásicos y postclásicos, que le prestan no pocos materiales para su erudición.

${ }^{23}$ Serv., auct. Ecl. 3.111. Sat prata biberunt]: aut intellegimus hunc exisse, ut iuberet pueris suis ut arva inrigarent, quod illis cantantibus factum est, et re vera dicit 'rivos claudite': aut certe allegoricos hoc dicit: iam cantare desinite, satiati enim audiendo sumus.

${ }^{24}$ Verg., ecl. 8.61.

${ }^{25}$ Cf. Macr., Sat. 3.2.11. 164: nam primo pontificii iuris libro apud Pictorem verbum hoc positum est vitulari: de cuius verbi significatu Titius ita retulit: vitulari est voce laetari. 
Además, el Gavinete mismo en su conjunto se inspira claramente en los Saturnalia de Macrobio, de donde toma la estructura de la obra como un diálogo en el que intervienen tres interlocutores en tres días sucesivos.

\section{Las fuentes renacentistas}

\subsection{Lorenzo Valla y Ravisio Téxtor}

Resulta significativo y hasta cierto punto sorprendente el uso de fuentes genuinamente renacentistas en una obra publicada a comienzos del siglo XIX. Salas Calderón demuestra conocer bien las Elegantiae de Lorenzo Valla, tal como pone de manifiesto en el pasaje de la segunda jornada que trata de las comidas de los antiguos romanos y más concretamente en el establecimiento de los significados exactos de algunos términos como epulae, epulum, dapes y cibus. Epulae son los manjares ordinarios y cotidianos; epulum es la comida solemne y pública; dapes son manjares que se suponían propios de los dioses o que los humanos comían en sacrificios; y cibus, finalmente, es una comida cotidiana de elaboración doméstica y particular:

"sobre todo lo cual me remito a Laurencio Valla en sus Elegancias"26.

También con cierta frecuencia acude a la Officina de Ravisio Téxtor, a los Hieroglyphica de Piero Valeriano y a los Emblemata de Alciato; es decir, tres enciclopedias fundamentales del humanismo renacentista. La Officina de Ravisio Téxtor es un completo repertorio de ejemplos notables de la antigüedad grecolatina, en su mayoría, que ilustran diferentes aspectos de la historia o de la sociedad. A diferencia de esta enciclopedia propiamente literaria, la obra de Piero Valeriano y los Emblemas de Alciato son una buena conjunción de imágenes y textos.

${ }^{26}$ Salas 1802: 85-86. L.Valla 1999: 444-445. Salas remite, sin embargo, al cap. 205 del libro 4 seguramente por seguir una edición que enumera los capítulos de corrido. En cualquier caso es posible que Salas también tuviera en cuenta el capítulo 53 del libro 4, donde se alude a cibus como el hipónimo del campo de la alimentación. 
La oda séptima - y no sexta, como erróneamente dice Salas - del libro 4 es una de las composiciones cuya traducción incluye Salas en el Apéndice del tomo primero de su Gavinete. Se trata de la afamada oda en la que Horacio advierte a Torcuato de la fugacidad de la vida y de la inexorabilidad de la muerte (Diffugere nives...). El traductor introduce una licencia en su versión, que consiste básicamente en una breve alusión a las Parcas $^{27}$.

En la nota correspondiente reconoce haber mantenido "el mismo concepto", cambiando, sin embargo, las palabras. Y con la débil excusa de haber mencionado a las Parcas introduce una digresión sobre el número, nombre y ascendencia de las mismas. En buena medida sus noticias proceden del capítulo correspondiente de la Officina de Ravisio Téxtor, según confiesa el propio Salas Calderón ${ }^{28}$. En otras ocasiones, sin embargo, no hay confesión de deuda, es decir, Salas Calderón elude reconocer su fuente. Así sucede, por ejemplo, en las explicaciones recogidas en la nota a la traducción de un verso de Horacio ${ }^{29}$. Todo lo dicho aquí sobre Minos, Dédalo, el laberinto y el Minotauro sigue de cerca la doctrina contenida en el capítulo sobre Iudices inferorum, que, no por casualidad, está inmediatamente a continuación del capítulo que trata de las Parcas en la Officina de Ravisio Téxtor. De aquí toma incluso la alusión al adagio Radamantheo pollere iudicio, "que significa", dice Salas, "ser un juez recto, imparcial e ilustrado"30.

${ }^{27}$ Salas 1802: 15 (Apéndice): "Pero cuando en sus garras inoportunas / las Parcas nos envuelven / y llevan donde están Tulio y Eneas, / no esperes ya que seas / otra cosa, que polvo y sombra vana".

${ }^{28}$ Salas 1802: 97-98 (Apéndice): "Esta expresión es una de las licencias que fue preciso tomar para la versificación, inmutando algo las voces de Horacio, que dixo: cuando morimos y caemos donde están Tulio y Eneas, que son sus materiales palabras, y en lugar de esto traducir: cuando las Parcas nos envuelven $y$ llevan donde están Tulio y Eneas, que es el mismo concepto, aunque sean algo diversas las palabras. Y ya que hicimos mención de las Parcas convendrá notar (...); y de ellas habla y trata Juan Rabisio Testor (sic) en su Oficina". Cf. cap. Parcae, deae fatales en Ravisio Téxtor 1551: 140.

${ }^{29}$ Cf. Hor., Carm. 4.7.21: cum semel occideris et de te splendida Minos / fecerit arbitria; que Salas traduce así: "Después que fallecieres y que Minos / te haya tomado cuenta" (Salas 1802: 15, Apéndice).

${ }^{30}$ Salas 1802: 99 (Apéndice). Ravisio Téxtor 1551:141. 


\subsection{Los Adagia de Erasmo}

Los refranes aparecen diseminados en diferentes lugares del Gavinete. Algunos de ellos, por cierto, son de inspiracion horaciana y tienen un cierto aire erasmiano; en algunos casos es posible rastrear directamente la huella no confesada de los Adagia de Erasmo. Así sucede, por ejemplo, en las tres referencias paremiológicas a las orejas.

Uno de los poemas de Horacio que traduce Salas es la llamada "sátira del importuno" o la "sátira del charlatán", en la que el poeta romano cuenta cómo, al pasear por la via sacra, se le acerca un conocido que le asedia sin parar de hablar, con el propósito de hacer méritos para introducirse en el círculo de Mecenas ${ }^{31}$. Cuando Horacio comprende que su insoportable acompañante no está dispuesto a dejarle tranquilo, dice resignado:

Demito auriculas, ut iniquae mentis asellus

cum gravius dorso subit onus ${ }^{32}$.

Y Salas lo traduce así:

«Mis orejas baxé, como el asnillo

que cargado seguir no puede al suelton ${ }^{33}$.

${ }^{31}$ De este personaje se hace eco Erasmo, al ponerlo como ejemplo de "pelmazo" que aburre y agota a su interlocutor. Cf. Erasmo, Lingua, Lugduni, apud Seb. Gryphium, 1538, p. 32: "¿Y si le hubiese abordado un pelmazo como el que Horacio nos describe en sus sátiras, tan pesado que no podía quitárselo de encima, tan molesto y tan dado a parlotear desmesuradamente sobre cualquier cosa, que resultaba insoportable?: El sudor, dice (Horacio), me llegaba a raudales a las plantas de los pies; mientras que él, charla que te charla, elogiaba las calles y la ciudad". Tomo la traducción de la versión que hemos preparado junto con C. Chaparro y M. Mañas, para la edición facsímil, precedida de introducción y acompañada de notas e índices, que ha preparado la Editora Regional de Extremadura, como uno más de los volúmenes de la llamada "Biblioteca de Barcarrota": Erasmo de Rotterdam, La lengua. Se añade el librito Sobre la vergüenza desmedida de Plutarco de Queronea, (Mérida, 2007; según la de Lyon, 1538).

${ }^{32}$ Hor., Sat. 1.9.20.

${ }^{33}$ Salas 1802: 31 (Apéndice). 
Luego, en nota a la traducción, Salas señala:

"Es una comparación muy acomodada y oportuna para denotar el poeta que quedó como desanimado y sin espíritu ni valor para resistirse a aquel hablador molesto y deshacerse de él, enviándole noramala a pasear, y se acomodó a que le acompañase y a sufrir su matraca, baxando como un asnillo sus orejas, que en ellos y en todo quadrúpedo son señal o indicio de viveza o de floxedad" 34 .

Demissis auriculis es también el título del adagio en que Erasmo advierte el origen horaciano de esta expresión y explica, a su vez, el sentido de la misma, en términos similares a los empleados por el autor del Gavinete $^{35}$. Cabe pensar que Salas Calderón lo tuvo en cuenta a la hora de traducir el texto de Horacio y de redactar la nota del Apéndice.

Otro tanto cabe decir del adagio Aurem vellere recogido por Salas implícitamente en la anotación del penúltimo verso de esta misma composición. Oppono auriculam, dice Horacio; "mi oreja alargo", traduce Salas, poniendo así de manifiesto la intención del poeta agraviado de testificar en contra del "pelmazo" y a favor de un litigante que, por fin, les sale al encuentro. La nota que explica el sentido de esta expresión coincide, y no por casualidad, con lo dicho por Erasmo en sus Adagia:

"Toca aquí la costumbre que había entre los romanos de que cuando alguno hacía testigos sobre alguna cosa, los iba a todos asiendo uno por uno de una oreja, y les tiraba de ella para que se acordasen y tuviesen presente el suceso sobre que habían de testificar; y por eso Horacio, como brindándose, acudió con su oreja y se ofreció a ser testigo contra el charlatán que tanto le había mortificado" (Salas 1802: 116 Apéndice) $^{36}$.

Una última alusión se encuentra en la glosa que Salas hace de uno de sus epigramas latinos y se inscribe en un contexto genuinamente poético.

\footnotetext{
${ }^{34}$ Salas 1802: 111 (Apéndice).

${ }^{35}$ Erasm., Adag. 4.6.99: Qui deiecto sunt animo, auriculas super humeros habere
} dicuntur. Ita Plato lib. de Rep. X (...) Sumptum est a iumentis, quae sic aurium motu testantur affectum (...) Inde est illud Flacci: Demitto auriculas ...

${ }^{36}$ Erasm., Adag. 1.7.40: 'Auren vellere' veteres dicebant admonere a priscu ritu sumpta figura, quo in ius ducturii quempiam aurem vellicabant, attestantes eum, quem quasi testem meminisse volebant. Inde Horatianum illud in Sermonibus: 'Et licet attestari; ego vero / oppono auriculam'/". 
"Las sinalefas amontonadas", dice uno de los personajes del Gavinete, "hacen duros algunos versos y que se necesiten para ellos las orejas de Midas". Para entender en sus justos términos el sentido del comentario de Salas conviene recordar la interpretación que hace Erasmo de esta expresión: "Tiene su origen", señala el humanista holandés, "en una fábula muy conocida de Midas, rey de Frigia, a quien Febo le puso orejas de burro por haber preferido la música de Pan a la suya. Aunque Midas las ocultó durante mucho tiempo con su mitra, finalmente el barbero las descubrió y se lo contó a todo el mundo. Por ello este adagio cuadra bien a los tontos que tienen grandes orejas y poco entendimiento"37. Así pues, las "sinalefas amontonadas" de las que habla Salas sólo son digeribles por lectores torpes que no reparan en la incorrección prosódica que ocultan. Está evocando, pues, el adagio de Erasmo titulado precisamente así: Midas auriculas asini.

\subsection{Los Hieroglyphica de Piero Valeriano}

A las fuentes paremiológicas hay que añadir los Hieroglyphica de Piero Valeriano, que son manejados ampliamente por Salas Calderón en muchas y muy diferentes ocasiones. Así sucede, por ejemplo, cuando atribuye a Numa Pompilio la costumbre de coronar la cabeza de los sacerdotes con una especie de lazo o diadema que servía de adorno en los sacrificios. El nombre de este adorno fue primero tutulus y más tarde titulus, que es como se nos ha transmitido y como podemos verlo en la portada de los libros:

"(los títulos) se ponen a la cabeza de ellos para significar lo que tratan y se contiene en ellos. (...) La forma de los antiguos títulos consistía en ser un adorno de lienzo elevado en alto, y de figura cónica, ligado y sujeto a la cabeza con unas cintas encarnadas que se llamaban fascias y vitas" (Salas 1802: 28-29).

Todo esto y lo que sigue es glosa, si no traducción, del texto de Piero Valeriano:

${ }^{37}$ Erasm., Adag. 1.3.67. 
Erat et aniculi sive redimiculi species, cui nomen tutulus prius, mox titulo fecerunt; ornamentum quippe capitis in sublime surgens, purpurea vitta redimitum, instar coni, galerive rosarum ${ }^{38}$.

Estos tituli, o "cintas", perduran, según el Gavinete, en las mitras de los obispos, en la tiara pontificia, y en las coronas imperiales, reales y ducales. Las explicaciones que siguen en el Gavinete sobre las diademas y otros atributos del sumo sacerdote de los hebreos están tomadas también de Piero Valeriano, aunque en este caso, a diferencia del anterior, Salas silencia su fuente.

En otro pasaje, en el que arremete contra el imperio de las modas y el sacrificio económico que supone someterse al cambio constante en los vestidos, se hace eco de una cita de Tertuliano que cuadra bien al caso: al preguntarle por los motivos que le hacían preferir el palio griego a la toga romana, Tertuliano respondió que se ponía la ropa imprescindible para ir vestido y no para ir con ella a cuestas, descubriendo así su escasa devoción por las veleidades de las modas siempre tan fluctuantes como onerosas ${ }^{39}$. La cita, una vez más, está tomada de Piero Valeriano, como también lo está la disquisición que hace en otro lugar sobre el velo nupcial que se denomina flammeus ${ }^{40}$ y otra sobre el origen de la heráldica ${ }^{41}$.

${ }^{38}$ P. Valeriano $1575: 303 \mathrm{r}$.

${ }^{39}$ Salas 1802: 56: “Tertuliano, que disculpándose con un su amigo que le notaba sobre que hacía poco aprecio de las vestiduras romanas y separándose de lo que era uso y ahora pudiera llamarse moda, prefería a la toga el palio o capa de los griegos, dice: Conscientiam denique tram perrogabo, quid te prins in toga sentias, indutum an ne onustum? Habere vestem an baiulare?". La cita corresponde, en efecto, al tratado De pallio (5.2) de Tertuliano, pero, en realidad, Salas la toma de los Hieroglyphica de Piero Valeriano (1575: 295r): Tertullianus, cum notaretur quod indumenta romana fastidiret pallioque potius vir tantus uteretur homo minime ambitiosus, causam tuetur suam evitareque se eo habitu et impensa et incommodum respondet, cum toga vestis sit admodum onerosa, ait enim: 'Conscientiam denique (...)".

${ }^{40}$ Salas 1802: 114-116; P. Valeriano 1575: 296r.

${ }^{41}$ Salas 1802: 153; P. Valeriano 1575: 312. 


\subsection{Los Emblemas de Alciato y los Comentarios del Brocense}

La relación completa de los emblemas citados en el primer tomo del Gavinete (incluido el Apéndice) es la siguiente ${ }^{42}: 91$ (Onni effigies. De his qui meretricibus donant, quod in bonos usus verti debeant) ${ }^{43} ; 123$ (In illaudata laudantes) ${ }^{44} ; 130$ (Remedia in arduo, mala in prono esse) ${ }^{45} ; 136$ (Nobiles et generosi) ${ }^{46}$; 150 (Res publica liberata) ${ }^{47} ; 162$ (Gratiae) ${ }^{48} ; 176(\text { Pax })^{49} ; 177$ (Ex bello pax) ${ }^{50}$; 178 (Ex pace ubertas) $^{51}$; y 198 (Cupressus) $^{52}$.

La presencia de emblemas en el Gavinete se justifica en parte por la necesidad de documentar las imágenes que habrían de acompañar a los epigramas que lucirían al paso de la visita real en Badajoz. Éste es el caso de los emblemas 130 (Remedia in arduo, mala in prono esse), 176 (Pax), 177 (Ex bello pax) y 178 (Ex pace ubertas). El resto de emblemas tiene una función estrictamente moral o didáctica, según el caso. El emblema 91 (Ocni effigies), por ejemplo, sirve para ilustrar la crítica contra el gasto excesivo en modas pasajeras, un tema que resulta recurrente en la primera parte del Gavinete:

"Debería avergonzarse el otro sexo de ser tan gravoso al nuestro y al estado, y del desenfreno y prurito de andar cada día inventando y usando modas nuevas, todas por lo común de poca comodidad, de mucho gasto [...]

${ }^{42}$ Ya en su día M. Mañas (2004: 499-508) llamó la atención sobre el importante papel que desempeñan los emblemas en el Gavinete de Salas y, más concretamente, en la preparación de las empresas y epigramas que debían exhibirse en Badajoz con motivo de la visita de los monarcas y del Príncipe de la paz, Manuel Godoy. En este sentido, Mañas analizó el uso de los emblemas 176, 177 y 178 en los epigramas latinos y su influencia en la figuración de las imágenes y en la composición de los versos.

${ }^{43}$ Salas 1802: 65.

${ }^{44}$ Salas 1802: 155.

${ }^{45}$ Salas 1802: 250.

${ }^{46}$ Salas 1802: 118-119.

${ }^{47}$ Salas 1802: 32-33.

${ }^{48}$ Salas 1802: 95 (Apéndice).

${ }^{49}$ Salas 1802: 245 ss.

${ }^{50}$ Salas 1802: 249.

${ }^{51}$ Salas 1802: 250.

${ }^{52}$ Salas 1802: 90 (Apéndice). 
y deberíamos confundirnos los hombres de ser en este punto tan indulgentes, que no procuremos contener al otro sexo dentro de los límites de la moderación y la razón, y con una culpable condescendencia y disimulo [...] hayamos de suscribir a nuestra aniquilación y a la ruina de toda la casa, representada bien al vivo en aquella ingeniosa emblema de Alciato, en que nos pintó al laborioso Ocno texiendo una cuerda de esparto, y detrás de él una jumentilla (símbolo de la mujer profusa y gastadora) que destrozaba y consumía cuanto él iba texiendo" (Salas 1802: 65).

Alude al emblema 91, titulado Ocni effigies, o "retrato de Ocno", en el que se describe e interpreta el mito de Ocno, un personaje simbólico que representa el trabajo inútil y eterno, pues la cuerda que trenza laboriosamente acaba siendo destrozada por una burra voraz. El epigrama de Alciato interpreta el mito en clave alegórica, pues al socaire de Pausanias interpreta la escena como una ilustración de un hombre trabajador que sufre la desgracia de estar casado con una mujer derrochadora ${ }^{53}$.

Resulta obvio el propósito moralizador del Gavinete. En otros casos, sin embargo, la presencia del emblema responde a un simple afán de erudición. Pero antes de insistir en este punto, cabe preguntarse por qué a comienzos del siglo XIX un escritor como Salas Calderón acude aún a los emblemas de Alciato y no a otras colecciones de empresas e imágenes simbólicas más actuales. Varias son las razones que explican esta circunstancia. Unas son de índole interna, como es, sin duda, la magnífica conjunción de texto e imagen que proporciona la colección de Alciato, bien acogida desde la versión primera de 1531, y largamente imitada luego por otros tratadistas en colecciones igualmente famosas. En buena medida los emblemas de Alciato representan el inicio de un género artístico de amplio recorrido en la literatura y el arte de la edad moderna. Además de las razones internas, cabe aducir otras externas, como es el hecho de que en 1785 Gregorio Mayans publicara los Opera Omnia del Brocense que, como es sabido, contienen el comentario de Francisco Sánchez de las Brozas al libro de Alciato. No cabe ninguna duda de que Salas Calderón tenía a la vista el texto del Brocense y que se sirvió generosamente de él, según confiesa aquí y allá:

${ }^{53}$ Cf. Paus. 10.29.2; P. Grimal, Diccionario de mitología griega y romana. Barcelona, 386; y A. Ruiz de Elvira (1975), Mitología clásica. Madrid, 497-498. 
"Del píleo ocurre poco que decir, porque todos saben que fue un adorno de la cabeza peculiar de los romanos y propio de los esclavos, que por legítima manumisión arribaban a su libertad, de la que era símbolo y jeroglífico, y dio asunto y cuerpo a la numismática para varias empresas y medallas que a cada paso ocurren en los autores antiguos, todas con la inscripción libertas; sobre cuyo asunto formó Alciato la emblema 150, cuya explicación desempeñó con la agudeza y destreza que las demás nuestro célebre humanista Francisco Sánchez Brocense" (Salas 1802: 32-33).

Y efectivamente, su explicación sigue al pie de la letra la que ofrece El Brocense y suyas son también las fuentes que alega Salas para la mejor intelección de los versos de Alciato y de la imagen que los ilustra ${ }^{54}$.

En tres ocasiones más Salas Calderón reconoce la deuda con el comentario del Brocense a los emblemas de Alciato y en todas ellas expresa su admiración por el humanista a quien tanto debe en temas de emblemática. Así, en la nota 13 a las traducciones de Horacio, dice en relación con las Gracias:

"Alciato formó de ellas un emblema, en el que y en el comentario del Brocense, puede verse lo que hay que saber respectivo a las tres Gracias" 55 .

En otro lugar, hablando de la luna como símbolo de la antigüedad y nobleza de los senadores patricios de Roma, señala:

"y sobre la alusión, origen y fundamento de dicho jeroglífico y distintivo de los cien senadores patricios, pues los plebeyos no le usaban, son dignos de verse Piero Valeriano, Alciato y el comentario de nuestro célebre humanista Francisco Sánchez de las Brozas" ${ }^{\prime 56}$.

Por último, el comentario del Brocense al emblema 123 constituye una autoridad en la explicación de los símbolos heráldicos, según vemos en la anotación siguiente:

${ }^{54}$ F. Sánchez 1573: 284.

${ }^{55}$ Salas 1802: 95 (Apéndice).

${ }^{56}$ Salas 1802: 136. P. Valeriano 1575: 329v; F. Sánchez 1573: 264 (emblema 136: Nobiles et generosi). 
"Los trofeos que han llegado a ponerse en los escudos y ser adorno de ellos envuelven un punto de antigüedad cuya explicación debemos a Alciato y a lo que escribió su comentador, nuestro humanista Brocense" ${ }^{57}$.

Menos atento estuvo, sin embargo, a la Gramática del Brocense, pues, al contrario de lo expuesto contundentemente por éste en la Minerva de 1587, (y antes en otras obras menores de contenido gramatical), Salas Calderón, dejándose llevar por algunas interpretaciones ya antiguas, sostiene que "Llamáronse Parcas en sentido como irónico, porque a nadie perdonan" 58 . Se trata de una explicación que El Brocense condena explícitamente en su obra cumbre, la Minerva de 1587:

Ad nauseam usque repetunt indocti grammatici antiphrasin figuram; Parcas enim affirmant dici quia nemini parcunt, et lucum, quia minime lucet; et huiusmodi sexcenta monstra. Sed ego illos hic, ut in aliis ornnibus, in media luce caligare uel potius caecutire ostendam ${ }^{59}$.

Hay que tener en cuenta que los Opera omnia publicados por Mayans no incluyen la Minerva del Brocense, aunque esta circunstancia no justifica la imprudencia gramatical de nuestro "anticuario". Y digo "anticuario" en el sentido que antaño tenía este término, como aficionado y amante de la cultura clásica, en su más amplio sentido, y no como se entiende hoy, más bien como simple y respetable intermediario en el comercio de obras de arte u objetos de época. En este sentido creo que a Salas Calderón le cuadra bien este término, pues su Gavinete es un ejercicio de erudición clásica y de afán moralizador, que sigue los pasos trazados por los grandes autores de la antigüedad, aunque en no pocos casos, explicados en la letra y en las imágenes de autores modernos. Su proyecto responde bien a la máxima clásica de lectorem delectando pariterque monendo ${ }^{60}$, tal como el propio autor repite en varias ocasiones a lo largo de su obra:

${ }^{57}$ Salas 1802: 155. F. Sánchez 1573: 246 (Emblem. 123, In illaudata laudantes): Trophaeum (...) est iudicium victoriae. Primum fiebant trophaea ex arboribus decisis ramis, et trunco hostiis spoliis decorato fiebantque ubi hostes terga vertebant. Nam trophaeum id significat.

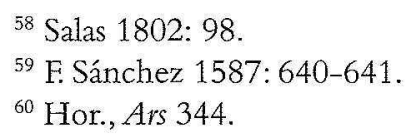


"Y esto es cuanto he podido adquirir y rastrear a costa de un serio y formal estudio de los poetas e historiadores y autores antiguos, sobre las vestiduras, adornos y calzado que usaron los romanos, [...] para diversión de Vuesas mercedes" $"$.

"En la conversación de mañana le toca hacer la costa y decirnos algo delicado que nos divierta e instruya" ${ }^{\circ 2}$.

\section{Conclusión}

Estas últimas líneas resumen bien el propósito del autor: "enseñar deleitando" y poniendo sobre la mesa conocimientos relativos a las antigüedades clásicas que sean parangonables con los usos propios del mundo contemporáneo. A Salas no le asiste sólo una suerte de inquietud arqueológica, que vemos en las disquisiciones más agudas sobre la correcta intelección de un término o un verso; le anima también un generoso afán vulgarizador, pues, como el propio Salas advierte por boca de uno de sus personajes, es necesario vulgarizar los conocimientos de la antigüedad "estancados en algunos pocos que poseen el latino"; y a todo ello hay que añadir un interés constante por explicar y, si es el caso, enmendar los usos y costumbres de su época a la luz del mundo antiguo.

\section{Bibliografía}

C. Chaparro (2003), "Juan de Salas Calderón, nuevo traductor de Horacio", Laurel 7 y 8: 125-143.

J. García (2006), “Tres facsímiles en torno a Godoy del fondo bibliográfico Clot-Manzanares", Revista de estudios extremeños 62. 1:177-188.

M. Mañas (2004), "Los epigramas latinos de Juan de Salas Calderón incluidos en el programa festivo para recibir a Carlos IV y $\mathrm{M}^{\mathrm{a}}$ Luisa de Parma (Badajoz, 1796)", in S. López (ed.), Florilegio de estudios de emblemática. A Coruña, 499-508.

M. Mañas (2006), Horacio. Arte poética y otros textos de teoría y crítica literarias, Universidad de Extremadura, Cáceres.

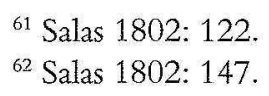

${ }^{61}$ Salas 1802: 122.

62 Salas 1802: 147. 
Ravisio Téxtor (1551), Alter tomus epitomes Officinae Ioannis Ravisii Textoris. Lugduni, apud Seb. Gryphium.

R. RODRíguez MoÑino (2000), La vida y obra del bibliófilo y bibliógrafo extremeño D. Antonio Rodríguez Moñino. Mérida-Madrid.

J. DE SAlAs CALderón (1802), Gavinete de antigüedades y humanidades. Tomo I. Madrid, Oficina de Ruiz.

J. DE Salas Calderón (1806), Tomo II. Valladolid, Imprenta y librería de Tomás Cermeño.

J. De Salas Calderón (1807), Tomo III. Valladolid, Imprenta y librería de Tomás Cermeño.

F. SÁnchez (1573), Commentaria in Andr. Alciati Emblemata, in Opera omnia una cum eiusdem scriptoris vita auctore Gregorio Maiansio, tomus tertius. Hildesheim, Georg Olms Verlag, 1985 (facsímil de la de Genevae, apud Fratres de Tournes, 1765; a su vez iuxta exemplar Lugdunense, anni 1573).

F. SÁnchez (1587), Francisco Sánchez de las Brozas. Minerva o de causis linguae latinae, E. Sánchez Salor y C. Chaparro Gómez (eds.). Cáceres, 1995.

P. VAleriano (1575), Hieroglyphica sive de sacris Aegyptiorum aliarumque gentium. Basileae, per Thomam Guarinum.

L. Valla (1999), De linguae latinae elegantia, ed. de S. López Moreda. Cáceres. 